\title{
Stigmatization of the Analytical Concept of Gender as Ideology
}

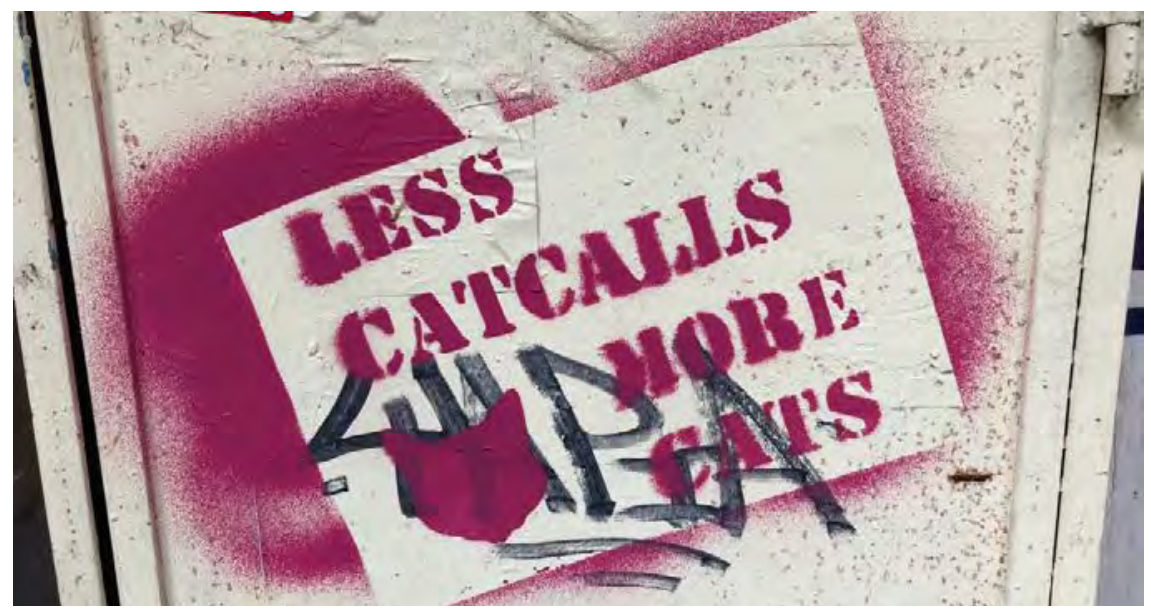

7 he stigmatization of 'gender' as the category of feminist ideology has become a central element of the political discourse in Hungary since

2010. I identify three junctures of this process since the system change in 1989, which have emerged and crystalized into the discourses of 'gender ideology' and 'gender-craze'. This appropriation of 'gender', the key category in feminist analysis is a serious attack to stigmatize and ostracize its critical potential and existence. I shall reflect on the specificities of these changes and argue for a model of meaning in terms of polyvocality that is always already open to critique. We need such a socially situated model to reclaim gender as the critical category of analysis that has been developed to expose the very ideological interest of patriarchal institutions to re/produce unequal relations of power as given. The move is all the more necessary as most feminist researchers and activists' debates in Hungary in the face of the accusation of 'ideology' are caught within a divide between the post-structuralist under-

Photo: "Less catcalls, more cats!” Graffiti in Thessaloniki, Greece.

(C) Erzébet Barát, photo and text 2020

(C) Feminist Critique: East European Journal of Feminist and Queer Studies 2020, № 3, p. 113-123; http://feminist.krytyka.com (ISSN 2524-2733) 
standing that all meanings should be ideological and the claim to 'truth' of the structural (economic) dispossession of women over false agendas of identity politics. Despite the fierce criticism of the other they seem to be caught within the reversal of the same logic, enacting what Laurent Berlant $(1996,243)$ has called the spectatorial sports of self-destruction among harmed collectives in the public sphere.

\section{Epistemological framing}

In order to orient my reader on the subsequent journey from the start, I would like to establish that as a scholar who does critical studies of discourse I understand 'gender' as a social practice of distinction that emerges from within institutionally regulated practices, an important constitutive element thereof is the symbolic practice of signifying, the act of encoding the material practices one directly engages in doing or practices one is not enacting but reflects on from within the actual one. In short, practices always entail a practice of categorization and the emerging categories come to be embedded within orders of value, indexical of the institutions within which they emerge as concepts of/with particular intelligibility. The most important element of the above definition is the claim that making sense of the practice one engages in doing inevitably implicates articulating multiple reflections on other practices at different locations, moments of time and systems of value. This means that the model I am proposing is inherently plural; the emerging categories in the process are necessarily organized by plurality. A category is made possible to emerge as a coherent and hence a meaningful pattern by a dialectic process of partial integration of diverse meanings from elements of meaning always already pertaining to multiple other fields of practices, hence other categories as an effect of the interplay of the dominant relations of ruling.

The point of departure of my reflections on the stigmatization of gender in the analysis below is the category of masculinity. I am fully aware of the potential disappointment about my choice due to the resentment to the effect that most of the space and attention is already given to men. The relationship between women and power has always been uneasy ${ }^{1}$. Yet, in order to expose and understand the privileges that are at stake in the current systemic discreditation of gender as ideology in the discourse of Hungarian politics, we need to expose the unsettling and unsettled gender relations of power mobilized by "aggrieved entitlement of masculinity" that fuels despair and rage across diverse groups of men. The internal division within feminist groups may dangerously play in the hands of this rage.

\footnotetext{
${ }^{1}$ See for instance: Sreberny, Zoonen 2000; Vavrus 2002; Lakoff 2003. They all address the conflictual relationship in the field of media, which is the primary discursive field my data is taken from.
} 
The concept of hegemonic masculinity is introduced by R.W. Connell in 1987, taking issue with the dominant approaches to gender in contemporary sociology at the time. He challenges the consensual, taken for granted conceptualization of the category as a self-contained set of pre-given character traits that should correspond to one's 'biologically given sex' and as such should have its corresponding typologies of 'gender roles' that are argued to be acquired in a top-down manner through a unidirectional developmental process of socialization. Ironically, then, the canonized model of sex is conceptualized in terms of a categorization practice that privileges 'male' as the 'obvious' principle of categorization rooted in biology and as such producing a distinction of binary opposition at the expense of 'female'. That binary may only allow for the researcher to explore particular social activities linked with the 'two sexes' and sort them out as if pertaining to one or the other 'gender role'. The way out of such a homogenizing static practice of categorization for Connell is to see gender as an active process of negotiations whose outcome (including the category of biologized sex) is the effect of dominant power relations. With James W. Messerschmid then in 2005 she revisits her own concept to see the explanatory power of the model in the light of the social changes of global capitalism. They conclude that the concept needs to be made more dynamic and that way, I would say, they can come up with a more complex explanation of social change - in terms of masculinity. They argue for the recognition of the plurality of masculinity and encourage researchers to study other forms of masculinity (such as blue-collar male worker, gay middle-class white man, subcultural hard rock male fan, Roma urban unemployed man, etc.) in addition to the hegemonic one. The ultimate objective should be to see the productivity of the other forms, to understand that any change to the ideal form of masculinity is the result of the struggle by stigmatized, excluded, or devalued and tolerated masculinities challenging and subverting their perceived value and position in the eye of the relations of ruling.

However, in agreement with my epistemological stance on multiplicity as constitutive of meaning, I say we need to make this masculinity model more dynamic. If the ideal(ised) form of masculinity becomes what it is perceived to be in its contested relationship with the various other forms in a socially regulated process of negotiation of their value, we need to make only one more but very important step and reflect on how we understand 'relationship' itself. I argue that polyvocality or heterogeneity is integral to all categories in so far as they emerge as a more or less coherent category articulated out of several other discursive elements/categories. The resulting category will be overlapping with the ones whose elements it has in common. Consequently, their boundaries cannot be imagined to be self-contained but overlapping and so of relative stability, always already open to reconfiguration. The possibility of change at the same time is not only the matter of logical possibility but that of political viability at a given historical moment as well and the latter serves as a relative but relevant limit to our (academic 
or activist) imagination. What can be imagined at a given historical moment within a given institutional space is the result of the various vectors of power relations in place during the process of change - the emerging patterns of meaning are therefore not the matter of an arbitrary free play of signifiers but a socially regulated discursive articulation of contingency.

The corollary of this argument, in my reading, is that meaning, the emerging concept is ideological in so far as it is to naturalize, play down, or make this contingency either a matter of pure chance or an inevitably homogenized given. Despite their oppositional stance, they would equally pre-empt the recognition that it is only particular meanings emerging within a given exclusionary power-matrix that make some meaning function as a stigma. The arbitrary arrangement of signifiers, meant to challenge the dogma of universal truth used against other meanings as false consciousness and as such ideology, however makes it necessary to say that all meanings are ideological. That is, there is no possibility to even imagine a politically viable moment of equal standing but infinite flows of hegemonic (i.e. hierarchical) reconfigurations of relations of power and categories of naming. Despite the defying effect of unlimited arbitrariness and the corollary of the ideological effect of any construction of meaning, there is one thing we can expose: infinite arbitrariness is not necessarily in a binary relationship with contingency. It is sufficient for the articulatory logic at play to be informed by a partial distinction. What is at stake is making a category perceived sufficiently different to be recognizable as distinct enough and then see if the multiple vectors of meaning may result in a configuration of equal standing. It is similar to what Denise Thompson $(2001,27)$ argues to be the case:" What we are always in is systems of meaning, whether [the given] meanings are ideological or not depends on whether or not they are used in the service of domination." Drawing on Thompson, I would like to contend that the contingency model of meaning emerging at the intersection of multiple socially regulated signifying practices may allow for us to imagine and negotiate a configuration where the matrix of power relations turns out not to be informed by hegemony and hence the meaning of categories embedded in the process can be articulated without ideological investments. To me, what is at stake in the feminist debates about what standpoint we should take to effectively fight against the contemporary discreditation campaign that discredits feminism as gender ideology, to be willing to go beyond the binary perception of the social situation as one that calls for (structural) reality instead of the always ideological cultural constructions (of identity politics) and assume, instead, this stance of positioned, discursively articulated polyvocality of meaning (the category of gender included).

Given that multiple relations of hegemonic domination constitute the contemporary status quo, the effectivity of a particular ideology hinges precisely on the familiarity of meanings often to the point of escaping (critical) recognition, working as 'common sense' knowledge and unquestionable 'truth'. Over the past nine years this is what has happened to the meaning of gender redefined as dangerous ideology and as such a legitimate target of 
hate attacks, a discourse that is, uniquely in the case of Hungary, is manipulated from within the various institutions of state power. Therefore, the question is not about negating the accusation rather about how to approach the actual state ideologies at play in the campaign especially the one/s in dominance. I therefore argue for the relevance of challenging and studying common sense meanings of gender in academic and non-academic discourses. Drawing on Michael Billig's (1995) work, I also argue against the collapse of the banal and benign in the assessment of various forms of 'unflagged' nationalism in political discourse and contend that studying what is usually devalued in academic scholarship through the routine appeal to the banality and hence irrelevance of common sense concepts to the effect of 'What is new about it?' is dangerous. Its danger consists in disregarding that the perception of anything as benign is made possible precisely for its passing as 'obvious', 'common sense'. Therefore, we need to try challenge that conflation and draw the relative but all the more relevant distinction between the meaning of banal and benign. In short, I also argue that the conceptualization of 'relationality' as a historically specific dialectical, partially inclusionary formation of relation applies then to the conceptualization of 'difference' as well. In agreement with James Paul Gee's (2014) model of discourse: differentiation is the discursive act of meaning making that emerges as the result of multiple dimensions of encoding practices, endorsing one pattern over other patterns of meaning as sufficiently in sync with what is perceived as intelligible in a given social space without any further reflection, as common sense.

\section{The three conjunctures in the discreditation of 'gender'}

The specificities of the order of political discourse in the past three decades in Hungary can be effectively studied in terms of the changes of the meaning of feminism and gender. It is particularly relevant for us to understand the current Hungarian official discourse of politics situated in the cartography of gender knowledge since it can be characterized by a routine attack on and sacrifice of the rights of women, sexual minorities and people with non-conforming gender identities as well as feminist academics in the wake of a right-wing populism where hate-speech has become the daily routine of communication. ${ }^{2}$ The stigmatization of 'gender' as ideology has become a central element of this state political discourse in Hungary since $2010 .^{3}$

\footnotetext{
${ }^{2}$ For a detailed critique of that populist political discourse see my recent study (Barát 2017).

${ }^{3}$ In fact the systemic verbal attacks resulted in the ultimate point of drafting a decree that should ban the discipline of gender studies from the national list of MA degrees on August 13th 2108, followed by its deletion from the national registry of degrees on October 13th simply published in the National Gazatte without any explicit further announcement. However, at the time of the development of the argumentation in the current paper these turns were yet to happen and so I could not consider them retrospectively. Yet, the trajectory of my arguments can sadly be exteded to the culminate in the state intervention.
} 
I can identify three junctures of meaning making of 'gender' since the system change in 1989 that have crystalized into common-sense discourses of gender ideology and 'gender-craze' of right wing populism - that can be, sadly, indirectly shared by self-identifying members of the feminist opposition in various public debates and publications. ${ }^{4}$ The first period comprises the 1990s. In it the various meaning-making practices evolve around the term 'feminism' predominantly in the printed political media. The meaning of feminism emerges at the intersection of three dominant discourses and very quickly comes to be collapsed into the scary figure of the feminist who is assumed to be unintelligent to judge the various media-identified harmful effects of feminism. However, in so far as she is represented as only a few crazy women, the implied readership of the various media products is safely protected by their expected outrage and disidentification with such dangerous figures. The three discourses are that of an anti-American discourse that sees feminism as an alien export, undermining the newly won autonomy of the country as well as that of the alleged interest of its women who should not go along with their American sisters' craze who should have gone 'too far' and take the (mostly wealthy celebrity men) to court and sue them for sexual harassment with no reason - either motivated by their greed or lesbian hatred for men. As an inevitable result she would be (rightly). The other intertwined discourse would contribute to this meaning with the accusation that these feminist women did not learn from their experience that the 'woman question' belongs to the failure of the communist past and the ideal 'new woman' of the system change would obviously want to leave that past behind. Finally, the feminist woman is a failure on its own term as well in that she refuses to acknowledge the importance of women's ways of knowing, disregarding the arguable satisfaction expressed by the majority of contemporary women.

These characteristic features I have discussed in detail (Barát 2005). What is of relevance of my points today, on the one hand, is the media's gate-keeping mechanism early on that invests in the discreditation of feminism as an ideology through its articulation as a new imperialist (American) ideology intertwined with the old communist one, and the oppression of the 'other' women's understanding of their life. On the other hand, my 2005 study has also shown that the little media space given to feminist self-definitions themselves against the hostile practices of othering comes to be caught within the hostile hegemonic discourses of gender in the media with the reformist female academics on the one hand in a most troubling agreement with the misogynist male position on the heterosexual myth of men and women as partners in a complementary relationship and the hardly present representatives of the critical voices of outlaw sexualities on the other. In short, the po-

\footnotetext{
${ }^{4}$ For a recent study that reiterates and endorses this unhelpful divide see Weronika Grzebalska, Eszter Kováts and Andrea Pető (2018).
} 
tentially autonomous voices come from precisely the violently marginalized non-heterosexual positions

that come to be the shared point of departure for both the misogynist (hetero)sexist male and reformist feminist voices in their hegemonic allegiance in defence of the hetero-gendered social order, even if for different reasons. (...) Insofar as (discursive) practices can be considered to be ideological in that they aim at maintaining the status quo by naturalizing the given hegemonic relations of patriarchal power, (...) the various types of discourses enacted in the definition of 'feminism' reinforce the patriarchal regulation of women's labour and desire precisely by taking gender as sexually pre-given (Barát 2005, 206-7).

The first decade of the 21st century then seems a quiet one, there are no further attempts at defining feminism for the general public. ${ }^{5}$ The work is predominantly taking place in academic institutions with no immediate interest voiced by the media or any other political institution. The third period then emerges in the wake of the discussion of the national curriculum of pre-schooler in Parliament caught in the very middle of the part political struggles in the finish of the national elections. However, this time the category is not feminism but gender that seems to have been functioning ever since as Ernesto Laclau's $(1996,44)$ empty signifier. In my understanding one of the most telling characteristic features of a right-wing populism is the production of social relations set up between two such empty signifiers as in reconcilable contradiction with one another through the routine use of hate speech. On the one hand that logic produces a homogenized 'manhood' around which the diverse social groups of 'our' men can easily and conveniently come together to re/imagine themselves as 'strong' defenders of the nation in the face of any event, institution or collective declared to be 'a hostile malicious threat' while safely failing to see that their sense of 'fairness' and 'legitimacy' has always been built on the backs of various others. The Government's right-wing populist communication appeals to the 'strength' of the nation vested in them to 'protect' our Christian family values of the 'real Europe' against the 'other' men, the homogenized Muslim male 'intruders' and - more indirectly - against the so-called gender and human rights craze of 'Soros-sponsored' civil organization and any research or academic teaching that should stand in support or literally 'behind' the 'invasion'. The ideological work of this empty signifier then is also desirable in that it brings all these diverse groups and events together around the empty signifier of 'our threatening alien', thereby legitimizing targeting anyone who then comes to be labelled, stigmatizes as one of them - without any further explanation or justification.

Although at the beginning of the past decade gender turns out to be the term that invites hysterical reactions in the parliamentary debate whereas

\footnotetext{
${ }^{5}$ For a detailed discussion of the period see Barát (2012) - available in Hungarian only.
} 
the government's proposed change suggests the promotion of tolerance in two regards: the instructors are recommended to choose activities in the preschool that should challenge gender stereotypes and embrace multiculturalism. Interestingly, in the debate the latter change was not even mentioned as problematic. The Christian Democratic Party, the most vocal faction against the change - for one more month in opposition - did not see any threat in other cultures yet. Their number one enemy turned out to be gender in the government's modest act of gender mainstreaming: they explicitly attacked the change as gender for them meant the ideological code 'hiding the real agenda' of making 'our children' lose their sense of male and female identity and so indirectly promoting the hidden agenda of the 'third sex'. the central left Government was accused of attacking 'its own people' and therefore the Christian Democrats promised to abolish the new policy as soon as they come into power; which they did first thing after the inauguration of the new minster of education (the exact same person who was attacking the central-left government's act as a hidden agenda of the 'liberal gay lobby'). It is in the wake of the Syrian refugee's arrival in the summer of 2015 through the Balkan route, when the intersection of the supporters of the 'migrant' and the 'gender-craze' may come together around the two interconnected empty signifiers of hate speech, the routine mode of communication in the country. But unlike elsewhere in Europe, this order of hate discourse is produced, its main characteristic features, the actual targets are defined and promoted from within state political institutions and intermediaries.

During 2010-2014, the first four-year period of the central-right wing government, the main terrain of discrediting gender is played out by actual government faction MPs against their women MP peers in the opposition in the middle of their speeches when reading a bill, or in their questions addressed to government members in the question time session. It is most telling that the disparaging statement of hate speech they receive when discussing the bills criminalizing domestic violence. Although in its second reading the law is passed but predominantly as an act that is seen to protect children and the violence is not called 'domestic' as that should associate the home and the family with sexual/physical violence which literally was argued impossible. Instead it is called violence in partnership. When fighting against the bill there were speeches whose logic resonated with liberal feminist agendas of protecting women's rights when explicitly arguing that if women gave birth to 'sufficient number of children first' - specified as three to five - there would be no reason for violence...(sic). In the second period of the current regime, 2014-2018, the context of producing hate speech and the selection of the 'proper target' is shifted from the MPs in power to the actual people in the highest offices. The Chair of the House, for instance, has also given voice to his concern about women unwilling to give birth, 'giving grandchildren to us' on several occasions and in this intensified stage, always explicitly naming the reason for the 'death of the nation': it is gender-ideology, it is gender-craze. 
Finally, since April 2018, the attack on 'gender' has been integrated into the general discrediting campaign and curtailing of academic freedom and autonomy. In a way, the stigmatization of gender and anyone brought into connection with it has reached its highest level of discrimination: questioning the scholarly standing of gender studies and thereby its key category of critical research and labelling it as pure ideology - successfully projecting its own act of political interference not the scientific field that would expose it just like that.

\section{In suspense}

In the current situation I believe there are two important moves we can do. One is building networks of solidarity that challenge the appeal to a national 'us'. In so far as that appeal is articulated by various populist political regimes across the globe, in response to the various crisis of global neoliberal capitalism, we should reach out and connect with one another. I believe that would consist in building an empty signifier on the left but one whose concept of identity itself would recognize plurality as constitutive of its formation. explore the possibilities of imagining an inclusionary act of belonging that, at the same time, does not get caught in the liberal discourse of humanitarianism that inform the various agendas of integration - ever more intensively losing grounds in the whole of EU by now. To do that, I shall draw on Butler's (2014) concept of vulnerability. It is all the more important as she develops the concept when considering the possibility of collective action and forms of political assembly. She appeals to the shared condition of human vulnerability and our sense of precarity and austerity that, in her ontology, nobody can will away as that is our primary vulnerability to others without which we would cease to be human (XIV). In the face of the coercive strategies of global power - which should obviously apply to the millions of dislocated people, to the millions of women and children in human trafficking - I think it is precisely this differential, queer logic that may expose the uneven distribution of the damaging powers of toxic masculinity.

I see the flight of the refuges to Europe, or the recent resistance of Brazilian and Polish women against the curtailing of abortion as a form of "performative bodily resistance at work that shows how bodies are being acted on by social and economic policies that are decimating livelihoods." (Butler 2015, 10) Yet, it is telling of the enormous strength of these people, who, in showing their embodied precarity, are also resisting those very powers that declare the refugees' life 'disposable', unworthy of grief.

The appeal to shared precarity is also addressed as a more desirable agenda in comparison with identity politics as in Butler's understanding the former would allow for a broader, by implication, non-exclusionary, understanding of 'demands' - based on the ontological condition of vulnerability of (human) life. Nevertheless, I think, inclusion is not that much of a matter of scale as the reference to a broader/narrower scope should imply. This inclusiveness of an empty signifier other than that of right-wing populisms 
multiple modes of stigmatizing exclusion is made possible, paradoxically, by the fact that the category of precarity is conceptualized to allow for imagining sharing the demand of liveable life in public spaces in the form of a political act of plural performativity - inviting all possible supporters as well to come together with the directly targeted. I claim that sharing should not be necessarily seen as impossible in the case of political acts by mobilizations around 'identity'. Identity (collective or individual) does not inherently operate through the production and maintenance of normative conceptions of belonging and nonbelonging - provided categorization is enacted in terms of a relative - not an absolute - distinction between the immediate and implied target of hate ${ }^{6}$. To me, Butler's distinction seems to produce a binary between a sharing that is associated with a universally imagined human condition of vulnerability over and against the articulations of particular demands linked up with identity.

If we accept the ontological premise that utterances (for their intelligibility) are structured by plurality, or multiplicity, that is the meaning of any category, including identity as well as precarity, is by definition polyvocal or dialogic, then all categories are informed by this multiple logic. Plurality is integral to all categories as a logical contingency. Consequently, the identity of the 'I' or 'us' is always already called into question in and by its differential modes of relating to others. Then the task to me is not that much to argue that identity as a category should necessarily fail to furnish what it means to live and act ethically together while precarity could deliver this by way of its necessary orientation to inclusion but rather to explore the genealogy of the categories themselves; to see whether the current historic conditions of social struggle are more favourable towards an understanding of, or preference for, precarity over identity. What we should study then is the reasons for precarity to seem more of a promising category in contemporary political thought than identity - whose dominant meaning is that of the possessive self of consumerism, a matter of lifestyle that can always be mobilized in the name of the ethic of individualized guilt. It may also be the case that the concept of precarity seems more productive in political thought because it has not become sedimented in the same way or to the same level of 'obviousness' as identity has either in academic or in non-academic discourses of progressive politics when we try to evoke people as a group of belonging. However, we still might argue, that an empty signifier that appeals to precarity still may bring about an 'us' as a result of its current meaning being more readily/directly ready to foreground that living socially is relational: "One's life is always in some sense in the hands of the other. It implies exposure both to those we know and to those we do not know; a dependency on people we know, or barely know, or know not at all" (Butler 2009, 14).

\footnotetext{
${ }^{6}$ For the importance of the inclusion of the 'rest' of a given society in addition to the immediately targted group of people, see Mari J. Matsuda et al. (1993).
} 
Barát, E. 2005. "The 'Terrorist Feminist': Strategies of Gate-Keeping in the Hungarian Printed Media" in Feminist Critical Discourse Analysis: Gender, Power and Ideology in Discourse, ed. by Michelle M. Lazar, 205-228. London: Palgrave.

Barát, E. 2012. “A 'politikai korrektség'-re hivatkozás ideológiai csapdái: A 2010es év óvodapedagógiai változtatásokra tett kísérletet kísérő társadalmi és politikai küzdelmek," In Gondolatok a toleranciáról, a másságról. Mi/Más 2. Konferencia 2010, ed. by Kádár Judit és Szathmáry Judit, 66-74. Eger: Esterháry Károly Főiskola.

Barát, E. 2017. "Populist discourses in the Hungarian public sphere: From right to left (and Beyond)?" Journal of Language and Politics. 16(4):535-550.

Berlant, L. 1996. The Queen of America Goes to Washington City. Essays on Sex and Citizenship. Durham, NC: Duke University Press.

Billig, M. 1995. Banal Nationalism. Thousand Oaks, CA: Sage.

Butler, J. 2004. Precarious Life - The Powers of Mourning and Violence. London and New York: Verso.

Butler, J. 2009. Frames of War. When is life greavable? London and New York: Verso.

Butler, J. 2015. Notes Toward a Performative Theory of Assembly. Cambridge, MA: Harvard University Press.

Connell, R. W. 1987. Gender and Power. Society, the Person and Sexual Politics. Hoboken, NJ: Wiley.

Connell, R. W. and J. W. Messerschmid 2005. "Hegemonic Masculinity." Gender and Society. 19(6): 829-859.

Gee, James Paul. 2014. An Introduction to Discourse Analysis: Theory and Method. Abingdon: Routledge.

Grzebalska, Weronika, Eszter Kováts, and Andrea Pető. 2018. “Gender as symbolic glue. How 'gender' became an umbrella term for the rejection of the (neo)liberal order." Breaking Feminism, ed. by L.M. Deese et al., 32-38. Berlin: Rosa Luxemburg Stiftung.

Matsuda, Mari J., Charles R. Lawrence, Richard Delgado, and Kimberlé Crenshaw. 1993. Words That Wound: Critical Race Theory, Assaultive Speech, and the First Amendment. Colorado and Oxford: Westview Press.

Lakoff, Robin. 2003. "Language, Gender, and Politics: Putting 'Women' and 'Power' in the Same Sentence." The Handbook of Language and Gender, 160-178. Hoboken: Blackwell Publishing Ltd.

Sreberny, Annabelle and Liesbet van Zoonen, eds. 2000. Gender, Politics and Communication. Cresskill, N.J.: Hampton Press.

Thomson, Denise. 2001. Radical Feminism Today. Thousand Oaks, CA: Sage.

Vavrus, Mary Douglas. 2002. Postfeminist News: Political Women in Media Culture. Albany, N.Y.: State University of New York Press. 